\title{
I.П. СОЛОВІЙ
}

\section{КОНЦЕПЦІЯ ПЛАТИ ЗА ПОСЛУГИ ЕКОСИСТЕМ: СВІТОВИЙ ДОСВІД І ПЕРСПЕКТИВИ П̈Ї ВПРОВАДЖЕННЯ У ЛІСОВОМУ СЕКТОРІ ${ }^{2}$}

Концепџія послуг екосистем опирається на ідеї взаємозалежності добробуту людини і стійкості екосистем. Послуги екосистем можуть бути оцінені кількісно, зокрема економічними методами, кожен 3 яких має переваги та недоліки. Їх вибір має бути обтрунтованим , виходячи з мети дослідження та особливостей об'єкта очінювання. Проаналізовано значення і сутність економічної вартості послуг лісових екосистем. Наведено перелік та детальний опис тринадчяти інструментів їх очінювання, які набули застосування на практиці у різник краӥнах. Найпоширенішими ринками послуг екосистем на міжнародному рівні є вуглецеві ринки, ринки з охорони боліт, ринки покращення якості води, ринки покращення постачання (кількості) води, ринки біорізноманіття. Критично очінено досвід низки краӥн та окремі проекти зі сприяння впровадженню схем плати за послуги лісових екосистем, аналіз яких буде корисним для вивчення можливості їх використання в лісовій галузі Украӥни. Вказано на обмеження, властиві ринкам екосистемних послуг і вагомість пошуку нових інституції, які б базувались на морально-етичних цінностях і стратегії співробітництва.

Ключові слова: добробут, економічна оцінка, лісова політика, послуги лісових екосистем, ринки екосистемних послуг

Вступ. Відвернення деградації ландшафтів, пом'якшення негативних наслідків зміни клімату та забезпечення менеджменту природних ресурсів на засадах сталого розвитку пов'язані з численними послугами екосистем (ПЕ) - покращенням запасів води, зв'язуванням вуглецю, культурними цінностями та ін. $[6,9,13]$. Тому представники науки та практики різних сфер діяльності не можуть ігнорувати концепцію послуг екосистем, яка перебуває у полі зору багатьох наукових дисциплін, отримала міжнародну політичну підтримку і набуває дедалі ширшого застосування на практиці. Потрібні нові підходи для поглиблення між- і трансдисциплінарних досліджень, які забезпечать урахування вартості послуг екосистем у всіх сферах економічної діяльності.

Добробут людини та стійкість екосистем взаємозалежні. Концепція послуг екосистем, яка опирається на ідеї важливості цієї залежності, набула визнання в національних екологічних політиках і законодавстві багатьох країн. Активізується діяльність щодо широкого кола питань, пов'язаних 3 послугами екосистем, їхнім картуванням, оцінюванням, визначенням потенційних продавців і покупців та механізмів компенсації, формуванням ринків цих послуг. Зокрема, Європейська стратегія щодо біорізноманіття до 2020 р. (Ціль 2, Захід 5) передбачає, що країни-члени ЄС повинні скласти карти та оцінити стан екосистем та їхніх послуг до 2014 р., а також здійснити економічну оцінку послуг і пропагувати їх інтеграцію в системи моніторингу та звітності на рівні ЄС до 2020 року. Зокрема, це потребує розроблення національних систем моніторингу та конкретних індикаторів. Рекомендують пов'язувати такі системи 3 моніторингом біорізноманіття, а також визначенням прогресу щодо сталості та добробуту на національному рівні.

Одним із пріоритетних стратегічних завдань екологічної політики України визначено «проведення до 2015 р. інформаційно-просвітницької кампанії щодо цінності екосистемних послуг на прикладі екосистем України, формування до 2015 р. та подальше застосування вартісної оцінки екосистемних послуг». Варто зазначити, що ефективність цієї кампанії була доволі низькою, свідченням чого є низький рівень обізнаності з концепцією екосистемних послуг як серед науковців, так і практиків у сфері охорони довкілля та використання природних ресурсів.

\footnotetext{
СОЛОВІЙ Ігор Павлович - дійсний член Лісівничої академії наук України, доктор економічних наук, професор кафедри екологічної економіки, Національний лісотехнічний університет України, м. Львів, Україна. Тел.: +38-032-239-27-78. E-mail: soloviy@yahoo.co.uk

2 Стаття базується на матеріалах дослідження, виконаного у співпраці з Всесвітнім фондом природи (WWF) у рамках Програма ФЛЕГ II (СІСП Схід) «Правозастосування й управління в лісовому секторі країн східного регіону дії Європейського інструменту сусідства та партнерства-2», яка покликана забезпечити підтримку в зміцненні систем управління в лісовому секторі країн-учасниць.
} 
Значення і сутність оцінки економічної вартості послуг лісових екосистем. Оцінка економічної вартості екосистемних послуг залежить від повноти розуміння цих послуг, хоч дуже складно визначити і дослідити всі послуги екосистем, а також передбачити, як саме ці послуги можуть змінитися внаслідок впливу діяльності людини. Брак цієї інформації часто призводить до недооцінки цих послуг.

Кожну послугу екосистем можна оцінити одним чи кількома способами залежно від вартості прямого використання, вартості непрямого використання чи вартості невикористання. Послуги екосистем можуть бути оцінені кількісно, використовуючи економічні методи (прямого ринкового оцінювання, затрат на подорож, умовного оцінювання та ін.). Кожен метод має переваги та недоліки, тому його вибір має бути ретельно обміркованим, базуючись на меті дослідження та особливостях об'єкта.

Наприклад, Марія Аная-Ромеро та співавтори [4] провели дослідження репрезентативних послуг лісових екосистем у Середземномор'ї (Андалузія, Південна Іспанія) за період 1956-2007 pp., застосовуючи та водночас аналізуючи різноманітні інструменти оцінювання. Регіон $€$ вартим уваги, зважаючи на багатство послуг екосистем, які втім постають перед численними загрозами - знеліснення, пожежі, інтенсифікація сільського господарства та промисловий розвиток. Для дослідження впливу змін у землекористуванні науковці проаналізували три основні, на їхню думку, послуги лісових екосистем: зберігання вуглецю, захист від ерозії грунтів та забезпечення коркового дуба на основі інтеграції численних поширених і нових методологій та підходів - наприклад, підхід соціально-екологічних систем було використано для концептуалізації об'єктів дослідження, для оцінювання рослинності застосовано метод МГЕЗК $[12,14]$.

У доповіді «Ecological and Economic Foundations» [15] представлено огляд послуг лісу і методів вартісної оцінки, найбільш придатних для різних еко- системних послуг (таблиця A2.1b Conceptual matrix based on forest ecosystem services, benefits/value types and valuation approaches). Одним із документів, що містять корисну інформацію про вартісне оцінювання послуг лісових екосистем, $є$ опублікована в 2012 р. доповідь Консультативної групи 3 питань фінансування Спільного партнерства щодо лісів. Інформація про прийнятні підходи, особливо в контексті умов, сформованих в Європі, також міститься у звіті «Стартової наради» Групи експертів процесу «Ліси Європи» (2012). Хоч оцінка є корисною для того, щоб сторони могли надати пропозиції для успішного функціонування механізму послуг лісових екосистем, наявність досконалого методу вартісної оцінки не $є$ обов'язковою передумовою.

Вартісна оцінка може використовуватися для визначення того, скільки готовий платити покупець, а також для розроблення механізму платежу, але головне, щоб усі сторони погодилися з розмірами плати, а не з тим, що ії можна повністю обгрунтувати науковим методом. Наприклад, у лісогосподарському секторі розміри плати іноді встановлюють, виходячи з прибутку, втраченого внаслідок відміни певних рубок і продажів деревини, тобто на основі методу, який може бути ефективним, навіть якщо визначити «справжню» вартість дуже складно. У підсумку не настільки важливо, з яких цифр почнуть перемовини учасники схеми плати за послуги екосистем, їм потрібно досягти компромісу, взявши до уваги такі фактори, як вплив, який чиниться на інші екосистеми, та їхню стійкість.

Захарій Крістін та його колеги розробили адаптивні рамкові умови RESTS (Restoration Ecosystem Service Tool Selector, Відбірник інструментів для розрахунку вигід відновлення для послуг екосистем), що дають змогу приймати кращі рішення у відборі інструментів для роботи з лісовідновленням та послугами екосистем [7]. У відбірнику наявні описи тринадцяти інструментів оцінювання екосистем (табл.).

Перелік та описи інструментів оцінювання послуг екосистем (адаптовано за Christin et al. 2016, c. 6)

\begin{tabular}{|c|c|c|c|}
\hline $\begin{array}{c}\text { Скорочен- } \\
\text { ня }\end{array}$ & $\begin{array}{c}\text { Назва інструменту } \\
\text { (або пояснення -- } \\
\text { за наявності) } \\
\end{array}$ & Розробник & Опис та посилання \\
\hline 1 & 2 & 3 & 4 \\
\hline ARIES & $\begin{array}{c}\text { Використання } \\
\text { штучного інтелекту } \\
\text { для ПЕ (Artificial } \\
\text { Intelligence for } \\
\text { Ecosystem Services) }\end{array}$ & $\begin{array}{c}\text { Баскський } \\
\text { центр зі змін } \\
\text { клімату }\end{array}$ & $\begin{array}{l}\text { Рамкові умови для інтеграції багатьох парадигм моделю- } \\
\text { вання в контексті просторового моделювання та оцінки } \\
\text { ПЕ. Підтримує інформацію, засновану на штучному } \\
\text { інтелекті та вибір моделей шляхом семантичного моде- } \\
\text { лювання для розрахунку потоків ПЕ від екосистем до } \\
\text { користувачів. } \\
\text { Villa et al. - 2014, http://aries.integratedmodelling.org/). }\end{array}$ \\
\hline $\begin{array}{l}\text { Co\$ting } \\
\text { Nature }\end{array}$ & $\begin{array}{c}\text { Розраховуючи } \\
\text { природу (Co\$ting } \\
\text { Nature) }\end{array}$ & $\begin{array}{c}\text { Королів- } \\
\text { ський коледж } \\
\text { Лондона та } \\
\text { AmbioTEK }\end{array}$ & $\begin{array}{c}\text { Інструмент картографування та моделювання багатьох } \\
\text { ПЕ з використанням глобальних даних. Розраховує ПЕ } \\
\text { як альтернативні вартості (наприклад витрати, яких } \\
\text { можна було б уникнути, якби послуги постачались } 3 \\
\text { неприродних замінників). Mulligan 2015, } \\
\text { http://www.policysupport.org/costingnature). }\end{array}$ \\
\hline
\end{tabular}


Наукові праці Лісівничої академії наук України: збірник наукових праць

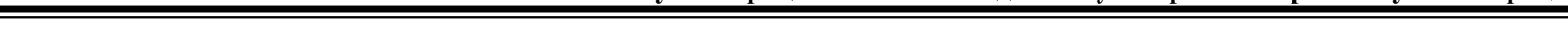

Продовж. табл.

\begin{tabular}{|c|c|c|c|}
\hline 1 & 2 & 3 & 4 \\
\hline EcoMetrix & EcoMetrix & \begin{tabular}{|} 
Група пошу- \\
ку рішень \\
Ecometrix та \\
Parametrix
\end{tabular} & $\begin{array}{c}\text { Польовий інструмент, розроблений для використання на } \\
\text { конкретних територіях. В основному призначений для } \\
\text { того, аби показувати вплив діяльності людей (напри- } \\
\text { клад розробка сценаріїв відновлення) на ПЕ (Есомеtrix } \\
\text { Solutions Group 2013, } \\
\text { http://www.ecometrixsolutions.com/ecometrix.html). }\end{array}$ \\
\hline EnSym & $\begin{array}{c}\text { Платформа мо- } \\
\text { делювання сис- } \\
\text { тем довкілля } \\
\text { (Environmental } \\
\text { Systems Modelling } \\
\text { Platform) } \\
\end{array}$ & $\begin{array}{c}\text { Штат Вікто- } \\
\text { рія, Австра- } \\
\text { лія }\end{array}$ & $\begin{array}{c}\text { Платформа для моделювання систем довкілля для до- } \\
\text { слідників, що прагнуть використовувати процесуальні } \\
\text { моделі. Розроблена, аби надавати інформацію про те, } \\
\text { як та куди інвестувати для досягнення максимальних } \\
\text { екологічних результатів } \\
\text { (Ha et al. 2010, https://ensym.dse.vic.gov.au/cms/). }\end{array}$ \\
\hline Envision & Envision & \begin{tabular}{|c|} 
Універси- \\
тет штату \\
Opегно \\
(Oregon State \\
University) \\
\end{tabular} & $\begin{array}{l}\text { Інформаційний інструмент, що використовує ГІС. Засто- } \\
\text { совують для планування та оцінювання на основі сцена- } \\
\text { ріїв. Дає змогу моделювати участь багатьох сторін для } \\
\text { представлення рішень людей у симуляціях щодо ланд- } \\
\text { шафтів (Guzy et al. 2008, http://envision.bioe.orst.edu/). }\end{array}$ \\
\hline ESR for IA & \begin{tabular}{c|} 
Огляд послуг еко- \\
систем для оці- \\
нювання впливів \\
(Ecosystem Services \\
Review for Impact \\
Assessment)
\end{tabular} & $\begin{array}{l}\text { World } \\
\text { Resources } \\
\text { Institute }\end{array}$ & $\begin{array}{c}\text { Метод для вивчення впливів та залежностей від ПЕ } \\
\text { проектів у рамках процесів оцінювання суспільних і } \\
\text { довкільних впливів. Пропонує заходи для зменшення } \\
\text { впливів проекту на вигоди від ПЕ та керування опера- } \\
\text { ційними залежностями від екосистем } \\
\text { (Landsberg et al. 2011, } \\
\text { http://www.wri.org/publication/ecosystem-services-review- } \\
\text { impact-assessment). } \\
\end{array}$ \\
\hline EVT & $\begin{array}{l}\text { Набір інструментів } \\
\text { для оцінювання еко- } \\
\text { систем (Ecosystem } \\
\text { Valuation Toolkit) }\end{array}$ & $\begin{array}{c}\text { Earth } \\
\text { Economics }\end{array}$ & $\begin{array}{c}\text { Забезпечує грошові оцінки для природних активів у } \\
\text { рамках різноманітних модулів. Містить дослідницьку } \\
\text { бібліотеку, пошукову базу даних вартостей ПЕ та веб-ін- } \\
\text { струмент SERVES для оцінювання вартостей ПЕ } \\
\text { (Earth Economics, 2015, http://esvaluation.org/) } \\
\end{array}$ \\
\hline InVEST & \begin{tabular}{c|} 
Інтегрована оцінка \\
послуг та компро- \\
місів екосистем \\
(Integrated Valuation \\
of Ecosystem \\
Services and \\
Tradeoffs) \\
\end{tabular} & $\begin{array}{l}\text { Natural } \\
\text { Capital } \\
\text { Project }\end{array}$ & $\begin{array}{c}\text { Просторове картографування та моделювання багатьох } \\
\text { ПЕ. Містить розмаїтий набір забезпечувальних, регу- } \\
\text { лятивних і культурних послуг земельного та водного } \\
\text { середовищ. Моделі переважно надають результати в } \\
\text { біофізичних величинах, до яких вже можна застосувати } \\
\text { оцінювання } \\
\text { (Sharp et al. 2014, http://www.naturalcapitalproject.org/). }\end{array}$ \\
\hline LUCI & \begin{tabular}{c|} 
Індикатор ви- \\
користання та \\
потенціалу (спро- \\
можності) земель \\
(Land Utilisation and \\
Capability Indicator)
\end{tabular} & $\begin{array}{c}\text { Університет } \\
\text { Вікторії Вел- } \\
\text { лінгтону }\end{array}$ & $\begin{array}{c}\text { Дає змогу досліджувати спроможність ландшафту за- } \\
\text { безпечувати різноманіття ПЕ. Порівнює ПЕ, що забез- } \\
\text { печуються існуючим користуванням ландшафту з його } \\
\text { потенційною спроможністю. У моделі ця інформація } \\
\text { використовується для визначення площ, де зміна чи } \\
\text { підтримка наявних умов може бути найбільш корисною } \\
\text { (Jackson et al. 2013, - http://www.lucitools.org/). } \\
\end{array}$ \\
\hline MIMES & \begin{tabular}{|l|} 
Багаторівневі (різ- \\
них рівнів масш- \\
табу) інтегровані \\
моделі послуг еко- \\
систем (Multiscale \\
Integrated Models of \\
Ecosystem Services) \\
\end{tabular} & $\begin{array}{l}\text { Affordable } \\
\text { Futures }\end{array}$ & $\begin{array}{c}\text { Платформа моделювання причинно-наслідкових взає- } \\
\text { мозв’язків між екосистемами та економікою. Дає змо- } \\
\text { гу створювати карти рішень/політик та спостерігати, } \\
\text { як ці рішення впливають на економіку та екосистеми } \\
\text { (Boumans et al. 2015, http://www.afordablefutures.com/ } \\
\text { orientation-to-what-we-do/services/mimes). }\end{array}$ \\
\hline NAIS & $\begin{array}{l}\text { Інформаційна систе- } \\
\text { ма природних акти- } \\
\text { вів (Natural Assets } \\
\text { Information System) }\end{array}$ & $\begin{array}{l}\text { Група про- } \\
\text { сторової } \\
\text { інформати- } \\
\text { ки (Spatial } \\
\text { Information } \\
\text { Group) } \\
\end{array}$ & $\begin{array}{c}\text { Інтегрована база оцінювання та формування звітності. } \\
\text { База даних інтегрована з інструментами просторового } \\
\text { моделювання для характеристики екосистем і потоків } \\
\text { послуг на певному ландшафті } \\
\text { (Troy and Wilson 2006, http://www.sig-gis.com/services/ } \\
\text { ecosystem-services/). } \\
\end{array}$ \\
\hline
\end{tabular}


Продовж. табл.

\begin{tabular}{|c|c|c|c|}
\hline 1 & 2 & 3 & 4 \\
\hline SolVES & $\begin{array}{l}\text { Соціальні цінності } \\
\text { для послуг екосис- } \\
\text { тем (Social Values for } \\
\text { Ecosystem Services) }\end{array}$ & $\begin{array}{l}\text { Геологічна } \\
\text { служба США } \\
\text { (US Geolo- } \\
\text { gical Survey) }\end{array}$ & $\begin{array}{c}\text { Інструмент просторового картографування та моделю- } \\
\text { вання, переважно спрямований на оцінювання культур- } \\
\text { них ПЕ через використання публічного ГІС із залучен- } \\
\text { ням зацікавлених сторін } \\
\text { (Sherrouse et al. 2011, http://solves.cr.usgs.gov/). }\end{array}$ \\
\hline Ок TESSA & $\begin{array}{l}\text { Інструмент міс- } \\
\text { цевої оцінки еко- } \\
\text { систем (Toolkit } \\
\text { for Ecosystem } \\
\text { Service Site-based } \\
\text { Assessment) }\end{array}$ & $\begin{array}{l}\text { Bird.life } \\
\text { Iternational }\end{array}$ & $\begin{array}{c}\text { Процес використання технологічних схем для опису } \\
\text { користі від ПЕ для суспільства в рамках дійсних умов, } \\
\text { а також альтернативних сценаріїв } \\
\text { (Peh et al. 2013) - http://tessa.tools/). }\end{array}$ \\
\hline
\end{tabular}

Незважаючи на труднощі, обмеження та проблеми оцінювання економічної вартості екосистемних послуг, реальна їх вартість часто перевищує економічну оцінку під час використання, тому збереження цих послуг має бути одним із найважливіших обов'язків політичних діячів і суспільства загалом.

Механізм плати за послуги екосистем та їхні ринки. Залежно від природно-господарських особливостей лісові екосистеми відрізняються, а тому і ринкові механізми змінюються відповідно до їхнього особливого екологічного, соціального або політичного значення. Залежно від рівня впливу держави можна виділити такі основні ринкові підходи: приватні угоди, відкриті схеми торгівлі та державні схеми фінансування. Найпоширенішими ринками послуг екосистем на міжнародному рівні $є$ вуглецеві ринки (carbon markets), ринки з охорони боліт (wetland mitigation banks), ринки покращення якості води (water quality markets), ринки покращення постачання (кількості) води (water quantity markets), ринки біорізноманіття (biodiversity markets).

У США, окрім механізму укладення угод щодо охорони земель (conservation easements), набули застосування прямі виплати і швидко розвиваються ринки екосистемних послуг лісів. Прямі виплати можуть здійснювати землевласникам від уряду кілька покупців, такі як компанії-власники електростанцій для придбання вуглецевих кредитів від землевласників, які займаються лісорозведенням.

Альтернативний варіант: великі групи людей можуть обміняти кредити на послуги новостворених ринків, такі як кредити на збереження боліт чи вуглецеві кредити на спеціальних біржах, таких як Chicago Climate Exchange. Ці виплати та ринки охоплюють широкий спектр послуг екосистем - від охорони вододілів, підтримання біорізноманіття та зникаючих видів до депонування вуглецю, охорони боліт від перетворень та забезпечення інших вигід. У деяких сферах вони все ще у зародковому стані, але різні виплати, пов'язані з охороною боліт, перевищили 1 млрд дол. У 2014 р. Рада ресурсів повітря Каліфорнії (CARB) надала перші компенсаційні кредити за Каліфорнійським протоколом відповідності. Вони були видані племені Юрок у Північній Каліфорнії, яке працювало протягом кількох років 3 приватною фірмою щодо інвентаризації, моделю- вання та реєстрації вуглецевих кредитів. У рамках системи $C A R B$ кредитується 10 лісових проектів 3 площею лісів 366,9 тис. акрів. Добровільні кредити також продаються для лісових проектів у США, зокрема за стандартом Verified Carbon Standard 58,2 тис. акрів лісових земель.

Значними $є$ напрацювання державних природоохоронних відомств Великобританії. Зокрема, одним із кращих взірців інструктивних матеріалів, розроблених задля сприяння впровадженню схем плати за послуги екосистем, є довідник «Плата за послуги екосистем: довідник кращих практик» (Payments for Ecosystem Services: A Best Practice Guide), розроблений Відділом довкілля, продовольства і відносин щодо сільських територій Уряду Великобританії (Department for Environment, Food \& Rural Affairs). Довідник містить стислий і дуже чіткий опис типів, принципів і механізмів дії основних схем, можливих їх учасників, можливостей та ризиків, пов'язаних із запровадженням схем плати за послуги екосистем, а також як окремий документ-додаток 3 детальним аналізом 17 прикладів впровадження схем як у різних частинах Великобританії, так і в інших країнах.

У Білорусії з ініціативи Міністерства природних ресурсів і охорони навколишнього середовища БілНДЦ «Экологія» спільно 3 іншими науковими організаціями у 2012 р. розробили «Порядок проведення вартісної оцінки екосистемних послуг» т. зв. технічний кодекс усталеної практики (технічний кодекс), який визначає методику вартісної оцінки екосистемних послуг та економічної цінності біорізноманіття для прийняття управлінських рішень в екологічній сфері та 3 метою розвитку платного природокористування. Роботу виконано в рамках реалізації Національної стратегії щодо збереження та стійкості використання біологічної різноманітності на 2011-2020 pр. (Затв. Пост. Радміну РБ No 1707 від 19 листопада 2010 р.), яка мала на меті адаптацію національного та зарубіжного досвіду вартісної оцінки екосистемних послуг, середовищетвірних функцій, а також економічної цінності біологічного різноманіття та сприяння його широкому застосуванню в Білорусі. Незважаючи не те, що методику офіційно затверджено у 2013 р., нам не вдалось знайти інформації про факти і результативність iii застосування на практиці. 
У Республіці Казахстан у 2012-2013 рр. проведено економічну оцінку екосистемних послуг Каркаралінського національного парку в рамках реалізації Проекту ГЕФ / ПРООН «Планування збереження біологічного різноманіття на національному рівні для підтримки реалізації Стратегічного плану КБР на 2011-2020 рр.». Згідно з результатами оцінювання, економічна вартість екосистемних послуг Каркаралінського ДНВП, обраних для оцінки в рамках цього дослідження, становила 86371 тис. дол., у т.ч. забезпечують послуги 1744 тис. дол., регулюють послуги - 77568 тис. дол., культурні послуги - 7058 тис. дол. Результати економічної оцінки екосистемних послуг ООПТ стали інформаційною основою для вирішення широкого спектра управлінських завдань - визначення частки природоохоронних територій у складі ВВП Казахстану, напрямок розвитку територій, що охороняються, визначення режимів природокористування, фінансування природоохоронних територій та своєчасного вжиття заходів щодо збереження біорізноманіття екосистем.

У Киргизії в рамках проекту в районі озера Icсик-Куль, який почали здійснювати у 2006 р. під керівництвом Регіонального Екологічного Центру Центральної Азії (РЕЦЦА), основну увагу приділяють розробленню п'яти різних схем плати за послуги екосистем. Один з експериментальних проектів спрямований на вдосконалення практики землекористування в районі водостоку в басейні річки Чон-Аксу та реконструкцію водопровідної мережі міста Темір. Мета проекту полягає у зміні практики водо- і землекористування на основі застосування екосистемного підходу. Завдання полягає в забезпеченні людей чистою питною водою шляхом поліпшення умов стокоутворення у верхній частині водозбірного басейну. Продавцем екосистемної послуги в рамках цього проекту є ліс, розташований у басейні річки Чон-Аксу. Федерація водокористувачів та населення оплачують додаткові витрати лісогосподарського підприємства, зумовлені застосуванням екосистемного підходу в практиці ведення лісового і пасовищного господарства.

У 2012 р. згідно 3 умовами Рамкової конвенції Організації Об'єднаних Націй про зміну клімату (РКЗК ООН) було оголошено про перші вуглецеві кредити, які було генеровано в рамках проекту «Збереження грунтів у Молдові». На ринок надійшло 851911 тимчасових сертифікованих скорочень викидів (ТССВ: одне ТССВ еквівалентно одній метричній тонні двоокису вуглецю) - найбільша кількість вуглецевих кредитів, які було генеровано по лінії проекту у сфері лісовідновлення в країнах, які приєднались. Проект було названо «прекрасним прикладом того, як співпраця між різними зацікавленими сторонами в рамках великомасштабного проекту в секторі лісового господарства дала змогу досягти позитивних зрушень» [16]. 3 урахуванням успіху цього проекту розроблено ще один проект «Розвиток лісового господарства на рівні громад у Молдові», який передбачає заліснення 8157 га еродованих і непродуктивних сільськогосподарських земель. У здійсненні цього проекту, який було розпочато в 2006 р., беруть участь агентство «Молдсілва» і 265 громад. Передбачено, що загальний обсяг інвестицій за період 2006-2035 pр. становитиме 21,7 млн дол. США.

Особливе зацікавлення зумовлюють проекти, пов'язані з оцінюванням й інтеграцією послуг екосистеми у процеси прийняття рішень, які ініційовані та виконуються за участю $W W F$ у Болгарії і Румунії. Зокрема, у Болгарії виконують проект "Розробка та впровадження моделі секторальної політики, орієнтованої на екосистемні послуги (PoliciES)". Робота над проектом на пілотній території Західна Стара-Планина має на меті створення першого плану лісовпорядкування на рівні регіонального управління 3 урахуванням плати за послуги екосистем. Проект використовує досвід і ноу-хау норвезького партнера щодо інтеграції послуг лісових екосистем і біорізноманіття на основі програмних рішень компанії, надаючи можливість оцінити вплив екосистемних послуг та біорізноманіття на ведення лісового господарства. Основна ідея щодо очікуваних результатів проекту “PoliciES" полягає у прагненні довести, що у процесі розроблення регіональних планів лісовпорядкування ключовим їх елементом мають стати екосистемні послуги, рішення щодо адаптації до зміни клімату та стале управління лісами. Апробацію цієї моделі та розвиток 27 регіональних планів ведення лісового господарства Лісове Агентство Болгарії виконає упродовж 20162017 років. Рекомендовано розглянути цей практичний досвід планування ведення лісового господарства в Україні, оскільки поточне планування його ведення бере до уваги обмежене коло функцій лісів, ігноруючи при цьому широкий спектр екосистемних послуг.

Очікувані результати проекту «Демонстрація та просування природних цінностей для підтримки прийняття рішень у Румунії» - це здійснення національної картографічної та біофізичної оцінки пріоритетних екосистем і екосистемних послуг відповідно до вимог процесу картографування й оцінювання екосистем та їх послуг (МАЕС), який триває на рівні Європейського Союзу. Проект пропонує рамки інституційного співробітництва, впровадження системи підтримки прийняття рішень і рекомендацій для Національного агентства 3 охорони навколишнього середовища $(N E P A)$. Інтегровану систему екологічної інформації (SIM) на цей час запроваджена на рівні $N E P A$ з урахуванням результатів проекту. Система дає змогу брати до уваги результати публічного опитування щодо екосистем і бази даних послуг екосистем, візуалізацію карт і даних. 3 погляду перспективи просування концепції в Україні платформа для картування екосистемних послуг та іï застосування у процесі прийняття політичних рішень становить особливий інтерес. Інший проект $W W F$ під назвою «Солідарність і повага до людей та природи» - пілотний проект для розроблення, тестування і введення в дію принципу щодо екосистемних послуг “вигодонабувач платить” у Румунії (SOLIDARON-PES Pay). Це дослідження було 
зосереджене на оцінюванні внеску лісових і прісноводних екосистем до різних секторів економіки шляхом оцінювання економічних витрат, пов'язаних 3 їх різними функціями і розподілу витрат на управління лісовими та прісноводними екосистемами серед безпосередніх користувачів/бенефіціарів на пілотній природоохоронній території. Результати проекту стосовно економічних аспектів оцінювання екосистем будуть корисними для вивчення можливості використання у галузі лісового господарства України, зокрема, питання оцінювання економічної вартості лісових і водних екосистем у межах природоохоронних територій і інтеграція цієї оцінки в галузеву політику.

Висновки. Як економісти, так і екологи закликають до ширшого використання ринкових інструментів для вирішення екологічних проблем, проте відсутність інструментів, які діяли б на рівні, потрібному для вирішення глобальних проблем, ускладнює можливість емпірично оцінити їх ефективність. Але ринок сам по собі не може забезпечити сталість екосистем та справедливий розподіл [8]. Як стверджує Дж. Фарлей та співавтори, у світі, де панує нерівність, впровадження таких інструментів зумовлює здорожчання сільськогосподарської продукції, що більшою мірою погіршує життя бідних, ніж багатих. Це стосується і концепції послуг екосистем, яка передбачає розвиток їх ринків, що посилює конкуренцію за використання природних ресурсів. Більшість екологічних проблем можуть бути охарактеризовані як «дилема в'язня», тому їх вирішення можливе шляхом співробітництва, а не конкуренції. Концепція плати за послуги екосистем дає змогу ідентифікувати широке коло послуг, зокрема ті, на які не звертали належної уваги, виявити їх просторове розташування, економічно оцінити та інтегрувати у процес прийняття господарських рішень, однак не є достатньою для досягнення сталості. Для забезпечення рамкових умов використання екосистемних послуг, які $є$ спільною спадщиною громад і людства загалом, потрібні нові інституції, які грунтуються на морально-етичних цінностях $i$ стратегії співробітництва.

\section{СПИСОК ВИКОРИСТАНИХ ДЖЕРЕЛ}

1. Закон України «Про Основні засади (стратегію) державної екологічної політики України на період до 2020 року». Відомості Верховної Ради України, 2011. - N 26. - С. 218.

2. Порядок проведения стоимостной оценки экосистемных услуг и определения стоимостной ценности биологического разнообразия. - Минск: изд-во Минприроды, 2013. - 21 с. [Електронний pecypc]. - Доступний 3 : http://tnpa.ecoinv.by/index. php?option $=$ com_content $\&$ view $=$ article $\&$ id $=74 \&$ Item id $=142$

3. Ценность лесов. Плата за экосистемные услуги в условиях “зеленой” экономики. Женевское иссле- дование по сектору лесного хозяйства и лесной промышленности № 34 Секция лесного хозяйства и лесоматериалов. - Женева, Швейцария, ООН, 2014. - 94 с.

4. Anaya-Romero, M., Muñoz-Rojas, M., Ibáñez, B., \& Marañón, T. (2016). Evaluation of forest ecosystem services in Mediterranean areas. A regional case study in South Spain. Ecosystem Services, 208290. doi:10.1016/j.ecoser.2016.07.002

5. Glaser, M., Krause, G., Ratter, B., Welp, M. (2008). Human-Nature Interaction in the Anthropocene: Potential of Social-Ecological Systems Analysis. GAIA 17 (1).

6. Chazdon, R.L. (2008). Beyond Deforestation: Restoring Forests and Ecosystem Services on Degraded Lands. Science, (5882). 1458

7. Christin Z., Bagstad, K., \& Verdone, M. (2016). A decision framework for identifying models to estimate forest ecosystem services gains from restoration. Forest Ecosystems (2197-5620), 3(1), 1. doi:10.1186/s40663016-0062-y

8. Daly, H.E. (1992) Allocation, distribution, and scale: towards an economics that is efficient, just, and sustainable. Ecol. Econ. 6, 18 - 193.

9. Dodds, W. K., Wilson, K. C., Rehmeier, R. L., Knight, G. L., Wiggam, S., Falke, J. A., \& ... Bertrand, K. N. (2008). Comparing Ecosystem Goods and Services Provided by Restored and Native Lands. Bioscience, (9), 837. doi:10.1641/B580909

10. Glaser, M., Krause, G., Ratter, B., Welp, M., (2008). Human-Nature Interaction in the Anthropocene: Potential of Social-Ecological Systems Analysis. GAIA 17 (1),

11. Farley, J., Schmitt, F. A., Burke, M., \& Farr, M. (2015). Extending market allocation to ecosystem services: Moral and practical implications on a full and unequal planet. Ecological Economics, 117244-252. doi:10.1016/j.ecolecon.2014.06.021

12. IPCC (2014). Climate Change 2013: The Physical Science Basis: Working Group I Contribution to the Fifth Assessment Report of the Intergovernmental Panel on Climate Change. Cambridge University Press.

13. Marin-Spiotta E, Ostertag R, Silver W (2007) Long-term patterns in tropical reforestation: plant community composition and aboveground biomass accumulation. Ecol Appl 17(3):828-839

14. Muñoz-Rojas, M., De la Rosa, D., Zavala, L., Jordán, A., \& Anaya-Romero, M. (2011). Changes in land cover and vegetation carbon stocks in Andalusia, Southern Spain (1956-2007). Science Of The Total Environment, 4092796-2806. doi:10.1016/j. scitotenv.2011.04.009

15. TEEB, 2010. The Economics of Ecosystems and Biodiversity: Mainstreaming the Economics of Nature: A synthesis of the approach, conclusions and recommendations of TEEB. - [Електронний pecypc]. - Доступний 3: http://www. teebweb.org/LinkClick.aspx?fileticket $=$ bYhDohL TuM\%3d\&tabid=924\&mid=1813.

16. World Bank and WWF, 2003. Authored by Dudley, N., Stolton, S. Running Pure. The importance of forest protected areas to drinking water. World Bank/WWF Alliance for Forest Conservation and 
Sustainable Use, August 2003. - [Електронний pecypc]. - Доступний 3 : http://wwf.panda.org/ what_we_do/how_we_work/conservation/forests/ publications $/$ ? $\mathrm{uNews}$ ID $=8443$.

\section{И.П. Соловий}

\section{КОНЦЕПЦИЯ ПЛАТЫ ЗА УСЛУГИ ЭКОСИСТЕМ: МИРОВОЙ ОПЫТ И ПЕРСПЕКТИВЫ ЕЕ ВНЕДРЕНИЯ В ЛЕСНОМ СЕКТОРЕ}

Услуги экосистем могут быть оценены количественно, используя экономические методы, каждый из которых имеет свои преимущества и недостатки, поэтому их выбор должен быть тщательно обдуманным, основываясь на целях исследования и особенностях объекта. Проанализированы сущность и значение оценки экономической стоимости услуг лесных экосистем. Приведен перечень и подробное описание тринадцати инструментов оценки услуг экосистем, которые разработаны исследователями и нашли применение на практике в ряде стран. Наиболее распространенными рынками услуг экосистем на международном уровне являются углеродные рынки, рынки по охране болот, рынки улучшения качества воды, рынки улучшения снабжения (количества) воды, рынки биоразнообразия. Критически оценены опыт ряда стран и отдельные проекты по внедрению схем платы за услуги лесных экосистем, анализ которых будет полезным для изучения возможности его использования в области лесного хозяйства Украины. Рынки экосистемных услуг сами по себе не могут решить экологических проблем, для обеспечения устойчивости развития необходимы институции, базирующиеся на стратегиях сотрудничества.

Ключевые слова: благосостояние, экономическая оценка, лесная политика, услуги лесных экосистем, рынки услуг экосистем

\section{Soloviy}

\section{CONCEPT OF PAYMENTS FOR ECOSYSTEM SERVICES: GLOBAL EXPERIENCES AND PROSPECTS OF ITS IMPLEMENTATION IN FOREST SECTOR}

The concept of ecosystem services (ES) has recently been gaining increasing recognition within national environmental policies and legislation of many countries. The Law of Ukraine "On Main Principles (Strategy) of National Ecological Policy of Ukraine until 2020" (2011) recognized "implementation of informational and educational campaign on the value of ecosystem services exemplified by ecosystems of Ukraine until 2015, elaboration until 2015 and successive use of ecosystem services valuation" as one of the major priorities of the ecological policy. The law has been barely effective, as can be witnessed by low conversance with the ES concept among both scientists and practitioners in the nature protection sphere, as well as by the absence of proliferation of ecosystem services valuation (ESV) into decision-making on economic and nature protection issues.

There is an urgent need in the development and implementation of the forest ecosystem services economic valuation, as elaborative and regulating elements of decision-making process within forestry sector. The ES concept helps to describe the benefits people acquire from nature and natural processes in ways that can influence policy and governance decisions. The ability of trees, forestlands and forests to provide a wide range of ES is greatly dependent on their disposition and the ways forest management is carried out regarding them.

Every ES can be assessed in one or several ways, which is dependent on the direct use value, indirect use value or non-use value. ES can be assessed in quantitative terms using economic methods (e.g. direct market valuation, travel cost, contingent valuation). Each method has its advantages and disadvantages, explored in the report. The choice regarding assessment method has to well considered, based on the research objectives and characteristics of its object.

Direct payments can be made to the forest owners from the government, introducing a few buyers, e.g. companies that own power stations can buy carbon credits from landowners who practice afforestation. Another option that can be used by large groups of people is the exchange of the ES offsets at the newly created markets - e.g. Chicago Climate Exchange. These payments and markets cover a great variety of ES - ranging from protection of watersheds, support conservation of biodiversity and endangered species to carbon sequestration, protection of wetlands from conversion, as well provision of other benefits. The most common international ES markets are: carbon markets, wetland mitigation banks, water quality markets, biodiversity markets.

Considering resemblance of natural conditions and socio-economic peculiarities of post-socialist economy particularly worth attention are projects regarding valuation and integration of ES into decision making implemented WWF in Bulgaria and Romania. It is recommended to consider this practical experience of forest management planning in Ukraine because current forest management planning considers a limited range of forest functions, while ignoring a broad range of ecosystem services. Solving global environmental problems will demand not only ecosystem services markets development but also new institutions based on idea of moral responsibility and cooperation.

Key words: well-being, economic evaluation, forest policy, forest ecosystem services, markets for ecosystem services 